\title{
Entre la intención poiética y el gesto político. La flor de la laguna y los orígenes del teatro musical en Concepción
}

\author{
Between the poietic intention and the political gesture. \\ La flor de la laguna and the origins of \\ musical theater in Concepción
}

\author{
por \\ Nicolás Masquiarán Díaz \\ Patricia Henríquez Puentes \\ Daniel Pereira Pereira \\ Juan Pablo Amaya \\ Grupo de Investigación Lenguajes Escénicos Teatro. \\ Facultad de Humanidades y Arte. \\ Universidad de Concepción, Chile. \\ lenguajesescenicos@gmail.com
}

En diciembre de 1965, el Teatro de la Universidad de Concepción (TUC, 1945-1973) estrenó la primera obra conocida hasta ahora que intenta una aproximación al teatro musical, producida íntegramente en su contexto local, La flor de la laguna de Roberto Navarrete Troncoso. Esta pieza revela prioridades estéticas, inquietudes políticas y disposiciones hacia los problemas contingentes que, en sus cruces, evidencian los regímenes de visibilidad e invisibilidad que definen los derroteros de la dramaturgia en un territorio de provincia. Con un enfoque basado principalmente en la historia local, se propone un análisis centrado en contenidos temáticos y musicales, que permita reconstruir la posición de La flor de la laguna como una singularidad dentro de la poiesis músico-teatral de Concepción, que responde a las necesidades de innovación, reivindicación de los contenidos locales y sensibilidad crítica hacia la contingencia político-social.

Palabras clave: Roberto Navarrete, Eduardo Gajardo, Teatro de la Universidad de Concepción, TUC, teatro musical.

In December 1965, the Theater of the University of Concepcion (TUC, 1945-1973) premiered the first known work that intended an approach to musical theater produced entirely in this local context: La flor de la laguna, by Roberto Navarrete Troncoso. This piece reveals aesthetic priorities, political concerns and dispositions to contingent problems that, in their intersections, show the regimes of visibility-invisibility that defined the paths of dramaturgy in a provincial territory. With an approach based mainly on local history, we propose an analysis centered on thematic and musical contents, which allows reconstructing the position of La flor de la laguna as a singularity within the theatrical-music poiesis of Concepcion, which responds to the needs of innovation, claims for local contents and critical sensitivity to contemporary political-social contingency.

Keywords: Roberto Navarrete, Eduardo Gajardo, Theatre of the University of Concepción, TUC, musical theatre.

Revista Musical Chilena, Año LXXIII, julio-diciembre, 2019, Nº 232, pp. 46-69 Fecha de recepción: 24-10-2017. Fecha de aceptación: 23-07-2018 


\section{INTRODUCCIÓN ${ }^{1}$}

Entre el 23 y el 26 de diciembre de 1965 se presentó en el foro de la Universidad de Concepción la primera obra teatral que, producida íntegramente en la capital del Biobío, buscaba aproximarse al emergente formato de teatro musical. La flor de la laguna, escrita por el actor, director y dramaturgo local Roberto Navarrete Troncoso (1925-1999), fue montada por el reconocido Teatro de la Universidad de Concepción (TUC) bajo la dirección del propio autor.

Como es frecuente en las iniciativas pioneras, se trata de una pieza cuya factura acusa las imperfecciones propias de un proceso de asimilación y aprendizaje. Es antes un producto de la voluntad de innovar que de un oficio consolidado. Así y todo, tiene algo más que el simple mérito de la primicia. La flor de la laguna se despliega desde un punto de confluencias históricas. Se detectan en ella las inquietudes por el desarrollo cultural de la ciudad, que inauguran una nueva modalidad de diálogo entre los mundos del teatro y la música locales. Al mismo tiempo, la obra da cuenta de cómo la comunidad artística de Concepción hace frente al devenir político del país con herramientas propias, respondiendo con iniciativas culturales a la contingencia sociopolítica durante una década plena de movimientos sociales, en la antesala del gobierno popular.

El presente trabajo fundamenta el valor de La flor de la laguna, poniendo esta pieza de dramaturgia local a contraluz de los acontecimientos que enmarcan e influyen en su poiesis: el estado del teatro musical chileno, el desarrollo del teatro y la cultura local y el acontecer sociopolítico de la circunstancia histórica en que se despliega. Nos preguntamos por el lugar que ocupa esta obra al momento de su realización, interrogándonos acerca de los posibles diálogos que establece con el medio cultural y político, en lo nacional y lo local. Enfatizamos en la revisión de las partituras adjuntas, pues consideramos que la música nos entrega indicios de esa posición.

Sostenemos la relevancia de este análisis descriptivo en tres razones fundamentales. Primero, porque hemos identificado en ella la primera obra de su naturaleza realizada en la ciudad de Concepción y, probablemente, en todo el sur de Chile. Segundo, por ser ilustrativa de una postura frente al momento histórico y político. Por último, porque nos permite poner en valor el legado creativo de Roberto Navarrete, uno de los creadores más prolíficos del TUC, cuyo aporte a la escena teatral de la ciudad de Concepción aún no ha sido suficientemente atendido.

Es nuestro supuesto que La flor de la laguna da cuenta de aquellas diferencias sustanciales en la forma de concebir la producción cultural entre las escenas de Concepción y Santiago, entendida esta última como espacio hegemónico. Estas distinciones estarían sujetas a condicionantes económicas y técnicas, pero también a la necesidad de una comunidad de artistas por declarar, mediante el teatro y la música, una posición ante situaciones de orden político y su efecto en la ciudadanía, desde una mirada local. En ese sentido, la obra que hemos escogido se perfila como una singularidad, dentro de la producción del teatro musical y la música nacional.

${ }^{1}$ El presente estudio se enmarca en el proyecto "Roberto Navarrete Troncoso, dramaturgo del TUC. La escena inconclusa", Fondart Nacional de Investigación $\mathrm{N}^{\circ} 413750$, desarrollado por el grupo de investigación Lenguajes Escénicos, de la Facultad de Humanidades y Arte de la Universidad de Concepción. 


\section{UNA APROXIMACIÓN DESDE EL TUC}

El año 1945 fue especialmente motivador para la agitada escena del teatro aficionado penquista. Su actividad se vio positivamente estimulada por la itinerancia de actores profesionales por la ciudad, que plantearon altas expectativas de calidad para las iniciativas locales. Fue ese mismo año que el elenco de la Universidad de Concepción inauguró públicamente sus actividades, con el montaje de La zapatera prodigiosa, de Federico García Lorca. Con este hito se convirtió en el tercer elenco nacional del emergente teatro universitario ${ }^{2}$.

Durante sus orígenes, el plantel estuvo integrado principalmente por alumnos y exalumnos de la casa de estudios; aficionados reunidos provisionalmente con motivo de los 25 años de la Universidad, en 1944, y que pronto evidenciaron su interés de proyección poniendo sobre las tablas aquel clásico del teatro español. La obra, dirigida por el joven abogado David Stitchkin Branover (1912-1997) tuvo una auspiciosa recepción entre la crítica y el público local. El diario La Patria señaló que, "el Teatro Universitario es la nueva forma de cultura ganada por los penquistas, con él ha aparecido un nuevo factor para agitar un poco los espíritus y dar mayor vida a los nobles afanes del arte (Contreras, Henríquez y Albornoz 2002: 77)".

Concepción solía depender de las iniciativas artísticas provenientes de la capital, de modo que sus habitantes casi siempre se mostraban llanos a respaldar la construcción de espacios para el desarrollo autónomo de la cultura, especialmente cuando estos venían avalados por el sello universitario. En ese sentido, los complejos vínculos entre universidad y comunidad trascendían lo institucional y convertían a la casa de estudios en un "incontenible movimiento espiritual (Louvel 1988: 300)", dando pie a que iniciativas tan potentes como el TUC lograran a la larga decantar hasta los cimientos mismos de la identidad local.

David Stitchkin era oriundo de Santiago, pero tras su temprano traslado a Concepción no tardó en conectar sus propios intereses con el ethos de la ciudad. Su aguda sensibilidad hacia las artes resonó empáticamente con la marcada inclinación por la cultura que profesaba la élite local. En lo práctico, esta cualidad se volcó hacia el teatro, de hecho fue miembro fundador del TUC y participó como actor o director en varios de sus primeros montajes, incluyendo, como ya mencionáramos, el debut del plantel. Pero su compromiso institucional y ciudadano llegó mucho más lejos. En 1956 asumió la rectoría de la Universidad de Concepción. Durante su administración desarrolló un proyecto de expansión y modernización institucional que, entre otros alcances, robusteció las actividades artísticas que se desarrollaban en la zona. Afianzó los planteles institucionales, subvencionó algunas iniciativas externas y favoreció la incorporación de las humanidades y las artes como áreas de formación profesional en la Universidad, que hasta ese entonces se había centrado en aquellas carreras que prestaran un servicio más inmediato frente a las necesidades sociales y los requerimientos técnico-profesionales del sur del país. De este modo, Stitchkin se instituyó en uno de los más sólidos soportes de la vida cultural de la ciudad.

Es importante considerar el intenso proceso de industrialización que vivió la zona desde el gobierno de Pedro Aguirre Cerda (1938-1941), con el consecuente incremento en la actividad de un mundo obrero que reconocía en la cultura y las artes herramientas posibles para conseguir un cambio en la sociedad. En ese sentido, la expansión del mundo

2 Previamente habían sido creados el Teatro Experimental de la Universidad de Chile (TEUCH, 1941) y el Teatro de Ensayo de la Pontificia Universidad Católica de Chile (TEUC, 1943). Le sucedieron el Teatro de la Universidad Técnica del Estado (TEKNOS, 1958) y el Teatro de la Universidad de Antofagasta (1962). Estos elencos dieron vida al movimiento de teatro universitario que vino a vigorizar la escena nacional hasta 1973 (Cánepa 1995, Fernández 1976, Piña 2014). 
cultural promovido por las instituciones locales se inscribe en una lógica de reestructuración social con fuerte vocación iluminista, que pudiera señalarse como una etapa clave en la consolidación de una identidad ciudadana.

Por supuesto, la relación estrecha de Stitchkin con las artes escénicas condujo a que el TUC tuviese una especial consideración entre los numerosos planteles que florecieron durante aquellos años. Este respaldo institucional se tradujo en varios efectos positivos que, desde la Universidad, se proyectaron hacia la práctica teatral de la zona en general. La agrupación se convirtió en un referente para toda la zona sur, labor que afianzó con la organización de numerosos festivales de teatro ${ }^{3}$, el apoyo hacia otras iniciativas de teatro aficionado ${ }^{4}$ y la itinerancia de sus montajes hacia localidades aledañas a Concepción.

En lo referente al tema que nos atañe, en 1958 se decreta la profesionalización del TUC $^{5}$. La consecuente contratación de actores, actrices y directores profesionales ${ }^{6}$, contribuyó a redefinir el perfil del elenco y, por supuesto, fue determinante en la selección del nuevo repertorio.

Durante la vida del TUC (1945-73) se llegaron a realizar 92 montajes documentados que, siguiendo a Marta Contreras, remiten a tres vertientes principales.

El repertorio de obras elegidas por el TUC para sus puestas en escena tiene una vertiente de teatro internacional contemporáneo, especialmente europeo y norteamericano; además, el grupo elige sus obras dentro de la tradición del repertorio clásico occidental, y del repertorio local de orientación nacional y regional (Contreras, Henríquez y Albornoz 2002: 28).

Sin duda, la profesionalización señala un hito significativo en la cronología del elenco. A partir de ese año nos encontramos con un aumento sustantivo en la cantidad y la diversidad de las obras. Durante el período 1945-57 se registran treinta y dos montajes, incluidas dos piezas de teatro nacional y una adaptación de poemas infantiles realizada por Stitchkin (Los niños y sus poetas, 1946). Entre 1958 y 1973, en cambio, se realizaron sesenta montajes, con diecinueve piezas vinculadas al teatro nacional. Se aprecia además una mayor consideración hacia la dramaturgia contemporánea, el teatro de vanguardia y, durante el gobierno de la Unidad Popular (1970-73), los autores latinoamericanos con inspiración política, que acapararon casi la totalidad de sus producciones del período.

En lo concreto, y pese al giro que se observó a partir de 1958, la producción dramática nacional no llegó a figurar como un interés prioritario, mientras que la local permanece en el extrarradio de los repertorios del TUC. Esta última categoría se restringe a tres autores: Gustavo Meza (La princesa que quería la luna, 1959), José Chesta (Las redes del mar, 1959; El umbral, 1967) y Roberto Navarrete (Su día gris, 1962; La flor de la laguna, 1965; La mariposa en el barbecho, 1969; Hora cero, 1972).

3 Entre 1956 y 1973 el TUC organizó 14 festivales de teatro, de alcance local y nacional, que convocaron especialmente a planteles de teatro aficionado, universitario e independiente (Cf. Contreras, Henríquez y Albornoz 2002).

4 Entre 1952 y 1972 el TUC gestionó diversos espacios para la formación en artes dramáticas, que incluyeron la Academia de Arte Dramático / Escuela de Teatro (1952-63), clubes y talleres universitarios. Además, fue una pieza clave en impulsar el desarrollo del teatro infantil en Concepción y sus alrededores (Cf. Contreras, Henríquez y Albornoz 2002).

5 Este gesto coincide con la profesionalización de la Orquesta Sinfónica Universitaria, dando cuenta de un proceso enmarcado en una visión institucional y no de una iniciativa aislada.

6 En 1958 ingresan al elenco Delfina Guzmán, Jasna Lubjec, Luis Alarcón, Jaime Vadell y Nelson Villagra, además del director Gustavo Meza (Cf. Contreras, Henríquez y Albornoz 2002: 130). 
La flor de la laguna y La princesa que quería la luna, del mismo modo que el Programa infantil (1961) y los Cuentos Folklóricos Chilenos (1971) -que completan el cuadro integral de las nueve piezas locales realizadas por el TUC- corresponden a representaciones de Navidad, pensadas con un perfil familiar y destinadas a un público amplio. En otras palabras, se trata de obras "menores" frente a los repertorios habituales del elenco. Un liviano contrapeso en aquel escenario dominado por autores consagrados, nacionales y extranjeros.

Considerando lo anterior, es posible afirmar que La flor de la laguna representa una marginalidad dentro de la producción histórica del TUC, por su ocasionalidad, su temática ligera y su carácter local. No obstante, también podemos defender su relevancia. Roberto Navarrete Troncoso fue el autor nacional más representado por el Teatro de la Universidad de Concepción, y uno de los más recurrentes en general, en los veintiocho años de historia de la agrupación. Fue además un integrante comprometido con los diferentes niveles de la actividad teatral desarrollada por el TUC: la actuación, la dirección y la creación. Por esta razón, capaz de generar una obra que sacara el máximo provecho a los recursos humanos y materiales de los que disponía el elenco.

\section{CARTOGRAFÍA MÍNIMA: ITINERARIOS HACIA LA FLOR DE LA LAGUNA}

Martín Farías (2014: 149-180) propone una cronología del teatro musical en Chile, inaugurado con Mapulai (1954), obra dramática escrita y dirigida por Raúl Aicardi, y musicalizada por Ernesto "Tito" Ledermann. Estamos frente a un teatro que explora en nuevos formatos, más llamativos, con vistas a ampliar sus horizontes artísticos, sin implicar en ello un giro hacia el espectáculo comercial, con el que generalmente se vinculaban este tipo de expresiones (Piña 2014). El argumento de Mapulai tenía por eje la usurpación de las tierras del pueblo mapuche, constatando con ello el vivo interés por abordar críticamente asuntos nacionales de alcance político. La obra obtuvo éxito relativo, antes por su carácter pionero que por su recepción.

Dos años más tarde se abrió paso la comedia musical con un retrato de la vida universitaria titulado $Y$... a veces estudiamos, de Rodolfo Soto, con letras de Ariel Arancibia y música, nuevamente, de Ernesto Ledermann. Pese a la expectativa que generó, no gozó de la aprobación de la crítica.

Fue Esta señorita Trini (1958), con libreto de Luis Alberto Heiremans y música de Carmen Barros, la comedia que logró la entrada definitiva del teatro musical al medio nacional. Elogiada por la crítica, fue la antesala de la celebérrima La pérgola de las flores (1960) de Isidora Aguirre con música de Francisco Flores del Campo, la obra musical más exitosa del teatro chileno y la primera en tener repercusión más allá de nuestras fronteras. Ambas producciones fueron realizadas por el Teatro de Ensayo de la Universidad Católica de Chile, misma compañía que, en enero de 1964, visita la ciudad de Concepción para realizar el estreno local de La pérgola... en una temporada de seis días ${ }^{7}$ (ver Figura 1).

7 “La 'Pérgola de las flores' debuta el próximo martes 28”. El Sur, lunes 20 de enero de 1964, p. 8. 


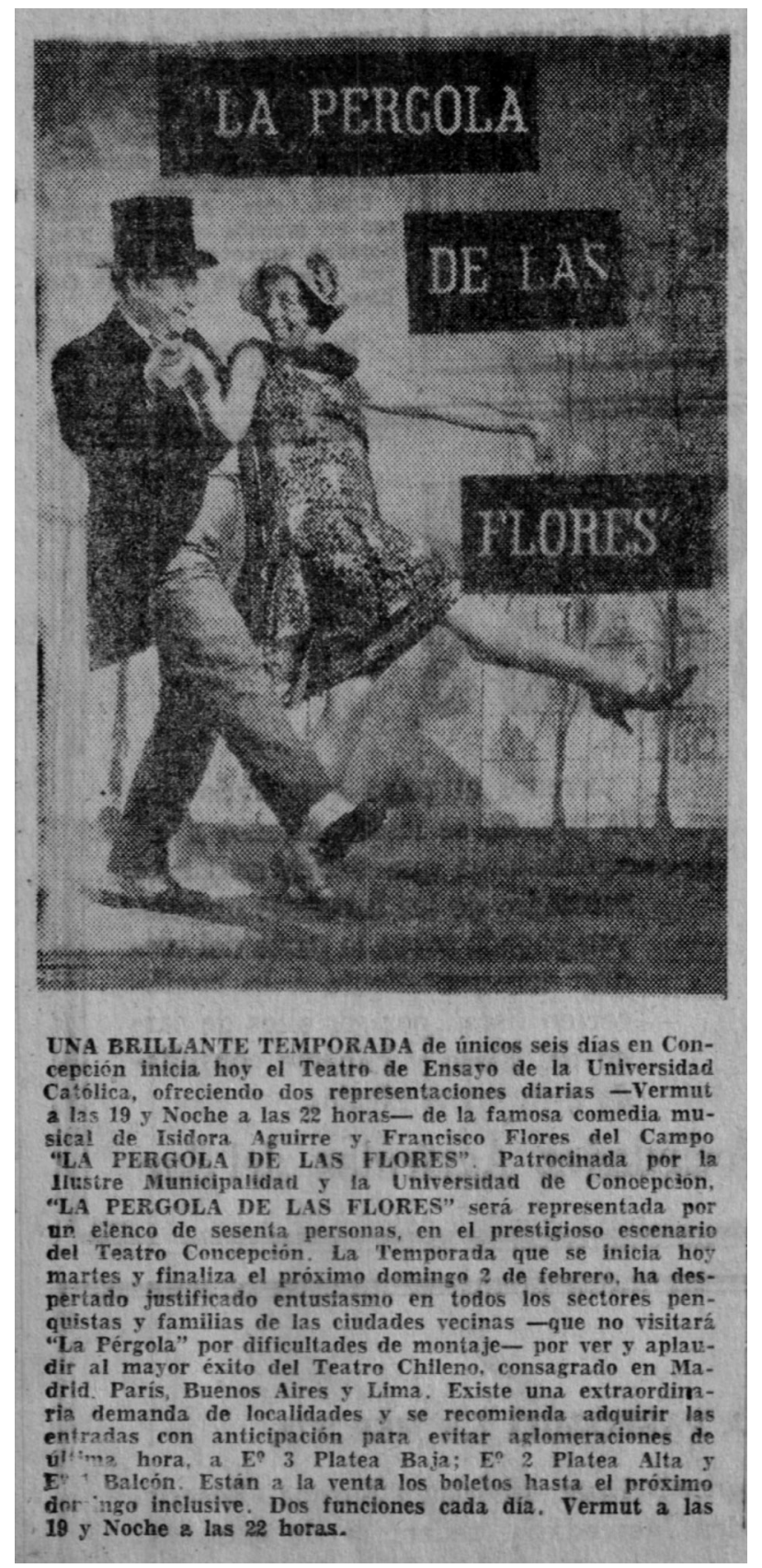

Figura 1: Anuncio de La pérgola de las flores.

Diario La Patria,

28 de enero de 1964, p. 3. 
Debido al impacto y vigencia de La pérgola de las flores durante sus primeros años, el elenco del TUC debía estar más que informado de su existencia. Podemos imaginar el efecto de contar con una obra de esa magnitud en los escenarios locales: un éxito rotundo frente al público y la crítica, con un despliegue escénico que exigía disponer de escenarios de primer nivel, impidiendo su itinerancia por ciudades más pequeñas ${ }^{8}$. En seis días y doce funciones acaparó la atención no solo de Concepción, sino también de las localidades próximas, y se instituyó en un nuevo punto de referencia para el teatro local.

En lo referente a La flor de la laguna esta influencia no se constata únicamente en su aproximación al formato musical. El aire de comedia que impera en La pérgola de las flores no la exime de deslizar gestos críticos al problematizar el encuentro campo-ciudad y, sobre todo, la resistencia al impulso modernizador representado en la lucha de las floristas por preservar su tradicional espacio de trabajo.

$\mathrm{Si}$ a todos estos antecedentes agregamos la receptividad de las audiencias al formato musical, en pleno auge gracias al efecto de la industria cinematográfica, y la relación preexistente del TUC con la dramaturga Isidora Aguirre ${ }^{9}$, es posible afirmar que esta confluencia da sentido a la aparición de esta primera aproximación penquista al teatro musical.

En este punto, sin embargo, es importante aclarar que si bien la tradición musicológica sitúa a la ópera y el musical como principales referencias de lo que aquí llamamos teatro musical, existe un sinfín de matices posibles en el diálogo entre música y teatro. En la literatura nacional estas parecen polarizarse hacia formas de espectáculo asociadas a la élite, la ópera y sus derivados, y formas populares relacionadas con el musical, que como ya sugerimos antes eran frecuentemente denostadas por comerciales, frívolas y hasta chabacanas y decadentes; más propias del espectáculo de variedades que de una dramaturgia seria (Piña 2014), aunque hasta cierto punto fueron legitimadas tras La pérgola de las flores.

La flor de la laguna se sitúa ciertamente en un punto de ese abanico donde predomina la dramaturgia por sobre la música. Por tanto, no se instituye necesariamente como una pionera en teatro musical como tal, sino como un primer intento declarado de inaugurar ese diálogo, inscrito en una lógica absolutamente local por su temática, sus posibilidades escénicas y las experiencias previas del elenco respecto de los diversos formatos dramatúrgicos que hasta ese momento les eran familiares. Dicho de otro modo y como detallaremos más adelante, observamos en esta iniciativa una clara conciencia del acontecer nacional, en sus dimensiones política, artística en general y teatral en particular, y desde ahí un interés por emprender hacia nuevas rutas creativas que den cuenta de las tendencias nacionales e internacionales del espectáculo teatral, pero enfrentado desde las limitaciones propias que impone un contexto donde, si bien existen referentes, no necesariamente existe la experiencia.

8 "En nuestra ciudad el Teatro de Ensayo de la U. Católica inicia su jira (sic) por las principales ciudades del sur del país y, lamentablemente, no se presentará en ninguna de nuestras ciudades vecinas de la provincia, por dificultades de montaje (El Sur, lunes 20 de enero de 1964, p. 8)".

9 Para 1964, el TUC había montado dos de sus obras de Isidora Aguirre: Dos más dos son cinco (1957) y Población Esperanza (1959). Esta última, escrita especialmente para el TUC en coautoría con Manuel Rojas, se convirtió en un clásico entre el repertorio del elenco, merecedora de múltiples reconocimientos (Contreras, Henríquez y Albornoz 2002). 


\section{ANATOMÍA DE LA FLOR DE LA LAGUNA ${ }^{10}$}

\subsection{Antecedentes generales}

La flor de la laguna de Roberto Navarrete Troncoso es una obra teatral de corte familiar destinada a ser representada en época de Navidad. Según las fuentes de prensa, se inspira en una leyenda campesina de la zona de Quillón ${ }^{11}$. Es decir, que la laguna mencionada referiría a la laguna Avendaño, lugar de esparcimiento que todavía es muy concurrido por los habitantes de la región del Biobío. Aunque no hemos podido encontrar una referencia más directa, probablemente se trate de una versión de la leyenda de la princesa del lago ${ }^{12}$.

Se estructura en un acto y ocho escenas, que acontecen en tres ambientes bien definidos: la "casa [de] pobres", de la familia del protagonista, en las escenas II, III y V; la "casa de ricos"13, en la escena VII y los exteriores, en las escenas I, IV, VI y VIII. Cuenta además con una gran cantidad de personajes en escena, más de una veintena en total, como se muestra en la tabla a continuación.

\section{TABLA 1: ESTRUCTURA DE LA OBRA. (SE INDICAN CON * AQUELLAS LOCACIONES EXPLICITADAS EN EL LIBRETO.)}

\begin{tabular}{|c|c|c|}
\hline Escena & Locación & Personajes \\
\hline I & Exterior & José, maestra, peón 1, muchachas 1 a 7 \\
\hline II & Casa [de] pobres* & José, madre, padre, abuelo, sobrina \\
\hline III & Casa de pobres & José \\
\hline IV & Exterior & José, maestra \\
\hline V & $\begin{array}{c}\text { En el hogar de los padres de José. } \\
\text { Dormitorio* (Casa de pobres) }\end{array}$ & Madre, padre \\
\hline VI & Exterior & José, maestra, peones 1 a 3, muchachas 1 a 7, \\
\hline VII & Casa de ricos [...]* & $\begin{array}{c}\text { José, niños 1 y 2, niña, madre [de los niños], } \\
\text { grupo de campesinos (extras). }\end{array}$ \\
\hline VIII & Exterior & $\begin{array}{c}\text { José, maestra, madre [de José], padre [de José], } \\
\text { niño 2, peones 1 y 2, muchachas 1 a 7. }\end{array}$ \\
\hline
\end{tabular}

10 La reconstrucción que se elabora a continuación se realizó principalmente a partir del libreto original mecanografiado conservado en el archivo personal de Roberto Navarrete Troncoso, facilitado por la familia. Con él se incluían cuatro partituras para coro, copiadas del manuscrito.

11 La localidad de Quillón se ubica en la provincia de Nuble, a 72 km al oriente de Concepción. Se trata de una zona característicamente campesina.

12 Una transcripción de la leyenda de la princesa del lago, en versión de Guillermo Cañón, se encuentra disponible en la página oficial de la Ilustre Municipalidad de Quillón: www.quillon.cl/ turismo/leyenda_la_princesa_del_lago.htm [acceso: 16 de septiembre de 2017].

13 Se utilizan de forma textual las denominaciones del libreto. 
Fue estrenada el 23 de diciembre de 1965, pero es posible que se la pensara originalmente para la Navidad de 1964, pues cinco de las seis partituras anexas al libreto aparecen fechadas por el copista en noviembre de ese año ${ }^{14}$. Frente a este antecedente y como señaláramos anteriormente, bien podemos suponer que el exitoso estreno local de La pérgola de las flores motivara la escritura de La flor de la laguna. Pero, más allá de los alicientes teatrales, medió también el afortunado encuentro entre un dramaturgo y un músico local que hiciera posible una creación de esta naturaleza: Roberto Navarrete y Eduardo Gajardo ${ }^{15}$.

Esta presunción se fortalece si consideramos que durante 1964 el TUC se encontraba en pleno proceso de reestructuración. El terremoto de 1960 singnificó la pérdida de su edificio teatral, al tiempo que desplazó los intereses y prioridades de la población hacia asuntos más urgentes que la cultura. Si bien la inestabilidad que esto acarreó fue contenida por la agrupación, para ese año se alcanzó un punto de crisis en lo económico y lo humano. Aunque el gobierno universitario de Ignacio González Ginouvés (1962-68) sostuvo algunas de las iniciativas impulsadas por su predecesor, David Stitchkin, nunca llegó a demostrar una sensibilidad tan aguda hacia las disciplinas artísticas. En cuanto al teatro, tuvo la intención de devolver al TUC a su condición inicial de elenco aficionado. Los conflictos de esta perniciosa disposición institucional generaron una diáspora entre los integrantes contratados durante el proceso de profesionalización. La significativa baja en la cantidad de montajes realizados contrastó con la intensa actividad de los años precedentes, obligando a declarar un receso durante el segundo semestre de 1964. Fue sin duda uno de los períodos más complejos para el plantel ${ }^{16}$.

En 1965, en cambio, el TUC encuentra los espacios para recuperarse. Incluso para arriesgarse con iniciativas tan ambiciosas como lo fue La flor de la laguna, cuyas proporciones escaparon a cualquier producción anterior del teatro universitario.

\subsection{El argumento}

La historia se desarrolla en dos líneas temporales. Comienza con José, el niño campesino protagonista, perdido lejos de casa intentando explicar a un grupo de desconocidos cómo es que llegó al lugar donde unos peones lo acaban de encontrar dormido. De entre el grupo destaca la figura de una profesora, que se esfuerza por descubrir la procedencia del niño. José insiste en que llegó ahí buscando la flor de la laguna. Nadie de los presentes ha oído hablar de ella.

Su narración, a modo de racconto, nos traslada a la noche anterior, en casa de su familia. Ahí, en medio de una escena de corte costumbrista, escuchó la leyenda de boca de su abuelo. Según el relato, en una laguna de localización indeterminada, a dos jornadas de distancia de su casa, cada Nochebuena aparece una flor mágica. A quien la encuentre le

14 Las transcripciones aparecen firmadas C.O.S. (o COS), iniciales que corresponden a Carlos Orellana Salazar, copista habitual del Coro de la Universidad de Concepción durante las décadas de 1960 y 1970.

15 Eduardo Gajardo es guitarrista, compositor y director coral, actualmente radicado en La Serena. Fue asistente de Arturo Medina, director de los Coros Polifónicos de la Corporación Sinfónica de Concepción, y director del conjunto criollo de dicha institución. Para 1965 ejercía como director del Coro de la Universidad de Concepción. Es autor de numerosos arreglos corales, principalmente de piezas de raíz folclórica, que todavía circulan en el país.

16 Los detalles de estos conflictos se encuentran en la reconstrucción testimonial de Contreras, Henríquez y Albornoz (2002: 457-466). 
será concedido cualquier deseo que pida. Para el abuelo, la historia involucra el recuerdo nostálgico de su esposa fallecida. En el niño, en cambio, despierta la fantasía de convertirse en médico para ser un hombre de bien que ayude al prójimo y, sobre todo, a su familia.

Luego de un sueño relacionado con la flor de la laguna, el niño decide emprenderlas en su búsqueda y escapa de casa durante la noche moviéndose en una especie de trance sonámbulo. En este punto, la narración nos devuelve más o menos hacia el inicio. Mientras los padres de José ya han advertido su desaparición e iniciado su búsqueda, el niño continúa su aventura asistiendo por primera vez a una celebración navideña, que descubre espiando la casa de una familia acomodada. Los niños intentan explicarle lo que ocurre; no comprenden que alguien nunca haya celebrado la Navidad. Invitan a José a jugar con ellos y convencen a su madre de que se los permita. Cuando, entre juegos y conversación, José los convence de acompañarlo en la búsqueda de la flor, la madre interviene para detenerlos.

Entonces aparecen los padres de José. Ante el inminente castigo, con la intercesión de la maestra va a imponerse la alegría del reencuentro. Finalmente, a modo de moraleja, la profesora le explica a José que la flor de la laguna es en realidad una metáfora de la educación, y que aquel que se preocupe por su educación podrá ser y hacer lo que se proponga en la vida. Es decir, cumplir todos sus deseos.

\subsection{El perfil sociopolítico}

El compromiso con los problemas políticos y sociales hizo parte del sello que caracterizó al TUC. Esta faceta se evidenció en diversas decisiones. Por ejemplo, la de trascender los escenarios principales para llevar el teatro a poblaciones o ciudades del extrarradio penquista; su acción social por medio de la beneficencia; su vocación pedagógica, al promover la práctica del teatro aficionado en espacios diferentes de la Universidad, y, por supuesto, la visibilización de estos tópicos en los argumentos de sus producciones. Obras como Población Esperanza evidencian la disposición política que descubrimos en una fracción significativa de repertorios del TUC.

Esta posición frente a los acontecimientos políticos y las problemáticas sociales se evidencia en varias creaciones de Navarrete, aunque cada una de ellas profundiza en aspectos diferentes. En La flor de la laguna se plantean al menos tres tópicos contingentes, en diferentes niveles, desarrollados desde un enfoque izquierdista: la vida del sujeto campesino, la diferencia de clase y la escolaridad como motor de movilidad social. En efecto, para mediados de la década de 1960 se desarrollaban dos procesos político-sociales de suma relevancia para el país que se relacionan directamente con esas inquietudes: la Reforma Agraria y el llamado "Plan Extraordinario de Educación".

La Reforma Agraria fue un proceso extenso y complejo, cuyos orígenes en Chile pueden rastrearse hasta la década de 1920. En lo formal, fue impulsada por el presidente Jorge Alessandri Rodríguez (1958-64) a partir de 1962, e involucró ciertas medidas legales y políticas que promovieron el cambio en la estructura de propiedad territorial como estrategia para moderar la migración campo-ciudad y fomentar la producción. El proceso continuó, con diferentes matices, durante los gobiernos de Eduardo Frei Montalva (1964-70) y Salvador Allende Gossens (1970-73). En términos amplios, se procedió a la disolución de los grandes latifundios para distribuir los terrenos de cultivo entre los peones e inquilinos, con miras a mejorar sus oportunidades y calidad de vida. La declaración "la tierra es para el que la trabaja”, acuñada durante el período de Frei Montalva, es una de las consignas más características de este proceso, en el que se llegaron a expropiar más de seis millones de hectáreas de terrenos rurales. 
Se trató de un tópico contingente en la zona del Biobío, de significativa participación en la producción agrícola y forestal del país. Roberto Navarrete era oriundo de Bulnes, localidad vecina a Quillón. Esa relación volcó su sensibilidad social hacia lo campesino, otorgando un carácter distintivo a su producción, pues el perfil industrial del Concepción urbano y sus alrededores situaba al sujeto obrero como encarnación preferente de las problemáticas sociales.

Las alusiones a este proceso se aprecian en todas sus obras de temática campesina. $E l$ cochayuyero (1963), La mariposa en el barbecho (1969) y Navidad en la aldea (1970) son casos bastante directos que, desde diferentes enfoques, abordan las experiencias de desigualdad en el mundo rural, empatizando con la posición desfavorable de inquilinos y peones. En ellas, el autor denuncia las injusticias cometidas contra la clase trabajadora campesina y aboga por los efectos de dicho proyecto sociopolítico ${ }^{17}$.

En La flor de la laguna la consideración de Navarrete hacia lo campesino se abre a múltiples perfiles, representados tanto en los peones que encuentran a José al inicio de la primera escena como en la familia del niño, donde figuran los rasgos del inquilinaje. Su condición de marginalidad se remarca cuando se señala al hogar familiar como "casa [de] pobres". En las acotaciones se lo caracteriza como un "rancho campesino", remarcando la presencia de elementos costumbristas en la escena, como el brasero y el mate, y la figuración de frases como "Dejamos todo... listo ya. No va a tener de qué quejarse el patrón” (Navarrete 1965), al inicio de la obra.

En contraste, la Escena VII se sitúa en la "casa de ricos", que cautiva al protagonista. "¿Qué lindo! Si parece que estoy soñando (Navarrete 1965)”, declara. En ese espacio, los niños piensan en jugar y divertirse en lugar de trabajar. Allí la Navidad se celebra de una manera que, para un niño que nunca ha visto adornar un árbol o ha recibido un regalo, resulta absolutamente novedosa y deslumbrante.

Pero lo que encontramos en el eje central de la obra es la asimilación de la leyenda campesina como una metáfora de la relación entre educación y movilidad social, en plena implementación del "Plan Extraordinario de Educación", proyecto que abordó un eje prioritario de desarrollo nacional durante el gobierno democratacristiano de Frei Montalva. En él convergen las ideas del progresismo cristiano y las políticas de desarrollo propuestas por la Comisión Económica para Latinoamérica y el Caribe (CEPAL). Se pretendió generar cambios profundos en la sociedad chilena mediante la implementación de reformas estructurales en el sistema educativo que respondieran a,

la urgencia de otorgar a todos los chilenos la posibilidad real de ejercer el derecho a educarse, y la conciencia del papel acelerador que tiene la educación en el cambio económico y social, hizo que el Gobierno pusiera todo su esfuerzo en la rápida consecución de sus objetivos en relación con la educación, traducidos en metas que, por su alcance, produjeron un impacto nacional ${ }^{18}$.

La modernización del sistema y la democratización de las oportunidades de acceso a la educación se consideraron movimientos claves para superar la segmentación social, elevar el nivel de instrucción de la ciudadanía y afianzar una clase media ilustrada que

17 Otros aspectos de la dramaturgia campesina de Roberto Navarrete son revisados también en Henríquez, Pereira, Amaya y Masquiarán 2018.

18 Boletín de Educación $\mathrm{N}^{\circ}$ 1, citado en "Objeto del mes: La modernización de la Educación”. Casa Museo Eduardo Frei Montalva, 1 de marzo de 2013. Disponible en /www.casamuseoeduardofrei.cl/ objeto-del-mes-la-modernizacion-de-la-educacion/ [acceso: 17 de septiembre de 2017] 
contribuyera de mejor forma al desarrollo del país. Entre otras medidas, el plan se propuso incorporar a los profesores a una carrera docente, aumentar y mejorar la infraestructura y equipamientos para la educación, ampliar la matrícula y crear organismos de fiscalización, asesoramiento y apoyo. Todo esto con miras a garantizar la calidad de la educación impartida y ampliar al máximo su cobertura.

En lo que nos compete, es importante señalar que los sectores rurales y la educación general básica fueron objetivos prioritarios de la reforma. Para 1965 se esperaba el ingreso de 250.000 nuevos estudiantes a las aulas escolares, y hasta las comisarías y retenes sirvieron como puntos de matrícula. Pero además era importante convencer a la ciudadanía acerca de la relevancia de proporcionar esa educación temprana, de pensar en el niño como una potencia de movilidad social mediante el desarrollo cognitivo en lugar de fuerza de trabajo inmediata. En ese sentido, era posible encontrar en medios de alta circulación, publicidad como la que se observa en la Figura 2.

La aventura de José en La flor de la laguna concluye en una escena a modo de moraleja, donde, luego de la experiencia de haber contrastado la realidad de ricos y pobres, la maestra resignifica la metáfora de la flor mágica para allegarla a un plano de realidad.

Maestra: Lo que ustedes buscan, mis queridos niños, no es una flor material.

José: Bueno, y qué flor es entonces. ¿No es la que sale de la laguna?

Maestra: No es esa la que realmente buscan. ¿Saben ustedes cuál es?

Muchachas: La flor del saber y de la dignidad (Navarrete 1965).

Es decir, en un gesto de adscripción apunta a la educación de los niños desde un afán propagandístico, en pleno proceso de ampliación de matrículas y en medio de una afanosa discusión respecto de la viabilidad del ambicioso proyecto democratacristiano ${ }^{19}$.

Por último, todos estos elementos convergen en las líneas finales de la obra, donde en un gesto de integración, diferentes sujetos populares representados en la obra confluyen en un "coro" donde se proclama directamente la intención política subyacente. El momento se cierra con el comentario de la maestra, que le da a la consigna un carácter proyectivo.

"José: ¿Y dónde la encontraré?

Muchachas: En el estudio ahora y en el trabajo cuando seas un hombre.

José: Pero mis padres son pobres y no podrán mandarme al Liceo... ¿¿uándo?

Peones: Cuando ganemos un salario justo.

Peón 1: Y partamos el pan sin amargura.

Peón 2: Y nuestra sea la tierra que trabajamos y sudamos.

Peones: Y no tengamos que comer migajas de la mesa del odio y sus aliados.

Peón 1: Cuando no existan...

Todos: ¡Explotadores y explotados!

José: ¿YY cuándo será eso señorita?

Maestra: Ahora, en este momento en que comienza una nueva aurora para nuestra Patria. [...]" (Navarrete 1965).

19 Un interés más transversal de este aspecto se revela cuando leemos las palabras finales de $E l$ cochayuyero (Navarrete 1963): “iJuro que voy a aprender a leer! ¿Que voy a ser un hombre!”. La obra fue estrenada en agosto de 1965 por el elenco aficionado de la Escuela Dental de la Universidad de Concepción, en el marco del Primer Festival de Teatro para Universitarios. 


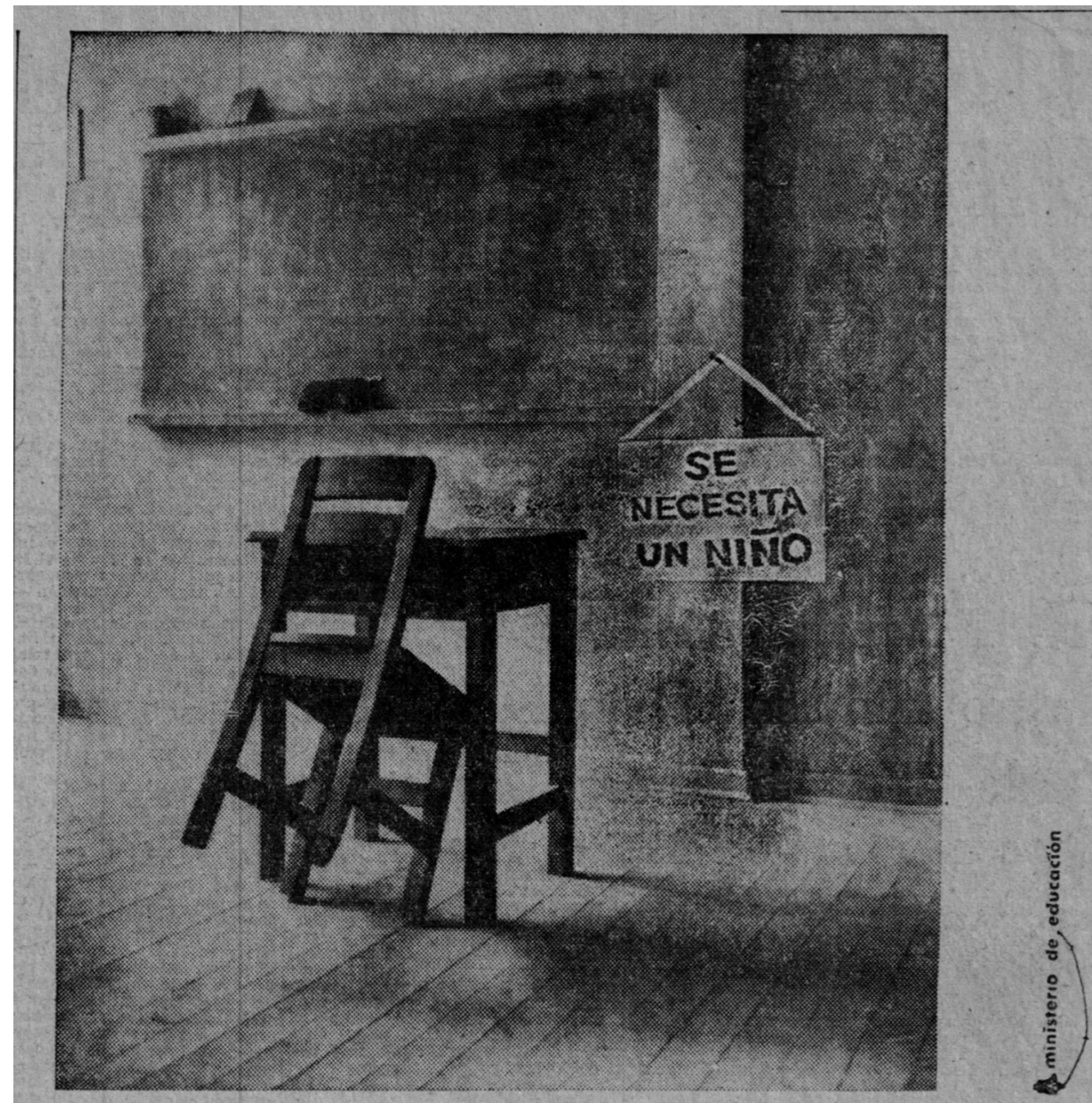

\section{ESTE BANCO ESTA RESERVADO PARA SU HIJO...}

Matricúlelo en la escuela primaria más cercana. Si no hay escuela, hágalo en el Retén de Carabineros.

Sin trámites, sin negativas, $\sin$ costo alguno, sin recomen: daciones, inscribalo entre el 7 y el 23 de Diciembre.

\section{AHORA... ESCUELLA PARA TODOS}

Figura 2: El Sur, 6 de diciembre de 1964, p. 29. 


\subsection{La realización}

El montaje de la obra requirió un despliegue humano y técnico sin precedentes en la historia del teatro local. Si bien los registros de prensa son inusualmente escasos considerando la magnitud de la obra, dejan bastantes indicios acerca de las exigencias técnicas y logísticas de la presentación.

El Foro Abierto se ha acondicionado esta vez a las necesidades de la obra, debiéndose instalar dos escenarios complementarios y laterales al escenario central que siempre se instala al pie de las aguas del fondo. También durante el curso de la obra se aprovecharán las caídas de agua, las que serán iluminadas lográndose con ello un efecto especial en el que sumado a un telón de fondo pintado especialmente por el conocido artista local Albino Echeverría, terminarán por ambientar esta obra que según su autor ha sido concebida tomando en especial consideración las características del Foro ${ }^{20}$.

La idea de aprovechar los atributos del Foro Abierto, "corazón del campus, centro social y cultural de la Universidad, abierto a todos y también punto de encuentro para la ciudad (Montealegre 1994: 102)", parece una acción estratégica. Lo que actualmente es un espacio integrado y rasgo distintivo de la identidad cultural local, para 1965 todavía revestía cierta novedad, pues se concibió como parte del proyecto urbanístico universitario de Emilio Duhart (1957) y su construcción fue retrasada por los graves daños que causó el doble terremoto de 1960. Es decir, La flor de la laguna también puede ser considerada como un gesto de innovación en el aprovechamiento del potencial de la nueva materialidad urbana, con miras a ampliar los horizontes de la cultura local, desde la colonización del propio territorio.

Pese a sus características excepcionales, la prensa apenas dejó registro gráfico de la obra en tres fotografías, dos de ellas muy similares entre sí (ver Figuras 3 y 4 ). Las escasas notas que llegaron a publicarse se limitaron a referencias descriptivas a modo de promoción, que invitaban a las familias de la zona a participar del evento. Sin embargo, no figura ninguna reseña crítica o referencia al impacto de la obra en cuanto a la afluencia de público o la recepción de la audiencia.

No hubo para Roberto Navarrete discursos periodísticos que, como en el caso de José Chesta en 1959, reflexionaran sobre la relevancia de valorar lo propio y eso que en este caso, lo propio poseía antecedentes "consagratorios", otorgados tres años antes por los mismos medios de comunicación penquistas. Por otra parte, no hubo para La flor de la laguna difusión del elenco que participaría en esta función de estreno (Contreras, Henríquez y Albornoz 2002: 212).

$\mathrm{Al}$ menos en el último punto podemos discrepar positivamente. Mientras El Sur presentó en una relación más bien general de los elencos involucrados en la obra, La Patria ofreció una enumeración detallada de los actores, actrices y roles que desarrollaron,

20 “'La Flor de la Laguna’ Esta Noche en el Foro”, La Patria, jueves 23 de diciembre de 1965, p. 6. La información se replicó en una nota similar publicada ese mismo día por el diario El Sur (jueves 23 de diciembre de 1965, p. 10). 
además de identificar claramente a los elencos aficionados involucrados ${ }^{21}$. Por otro lado, ambos medios informan de otras participaciones en la producción ${ }^{22}$.

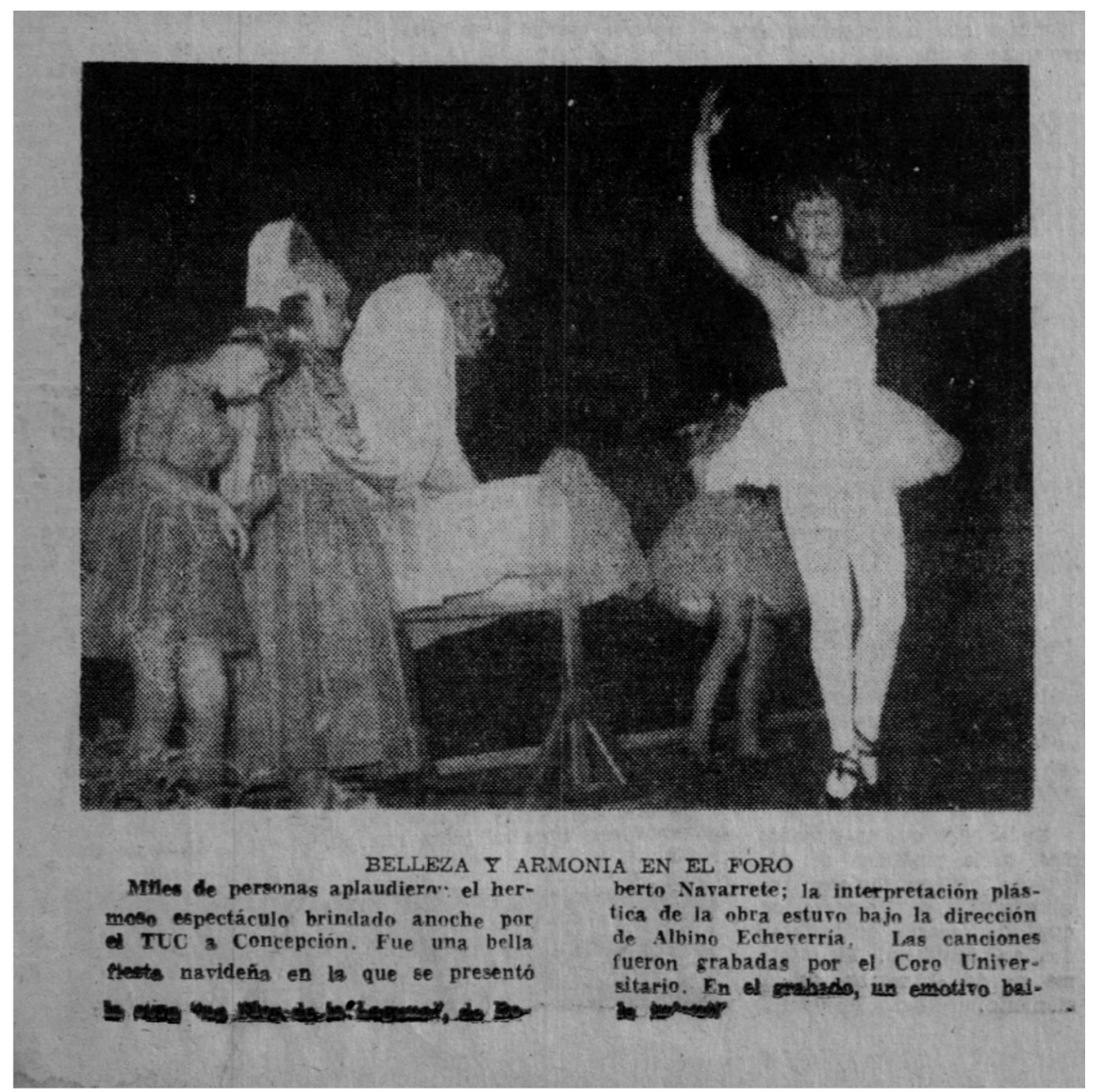

Figura 3: La Patria, viernes 24 de diciembre de 1965, p. 1.

21 "Espectáculo de Navidad Presenta Mañana el Teatro Universitario", La Patria, 22 de diciembre de 1965, p. 9, y "Con 'La Flor de la Laguna' TUC Inicia Presentaciones de Navidad en Foro Abierto", El Sur, 23 de diciembre de 1965, p. 10.

${ }^{22}$ Ver Anexo 1: Ficha Técnica, donde ampliamos la información disponible en Contreras, Henríquez y Albornoz 2002. 


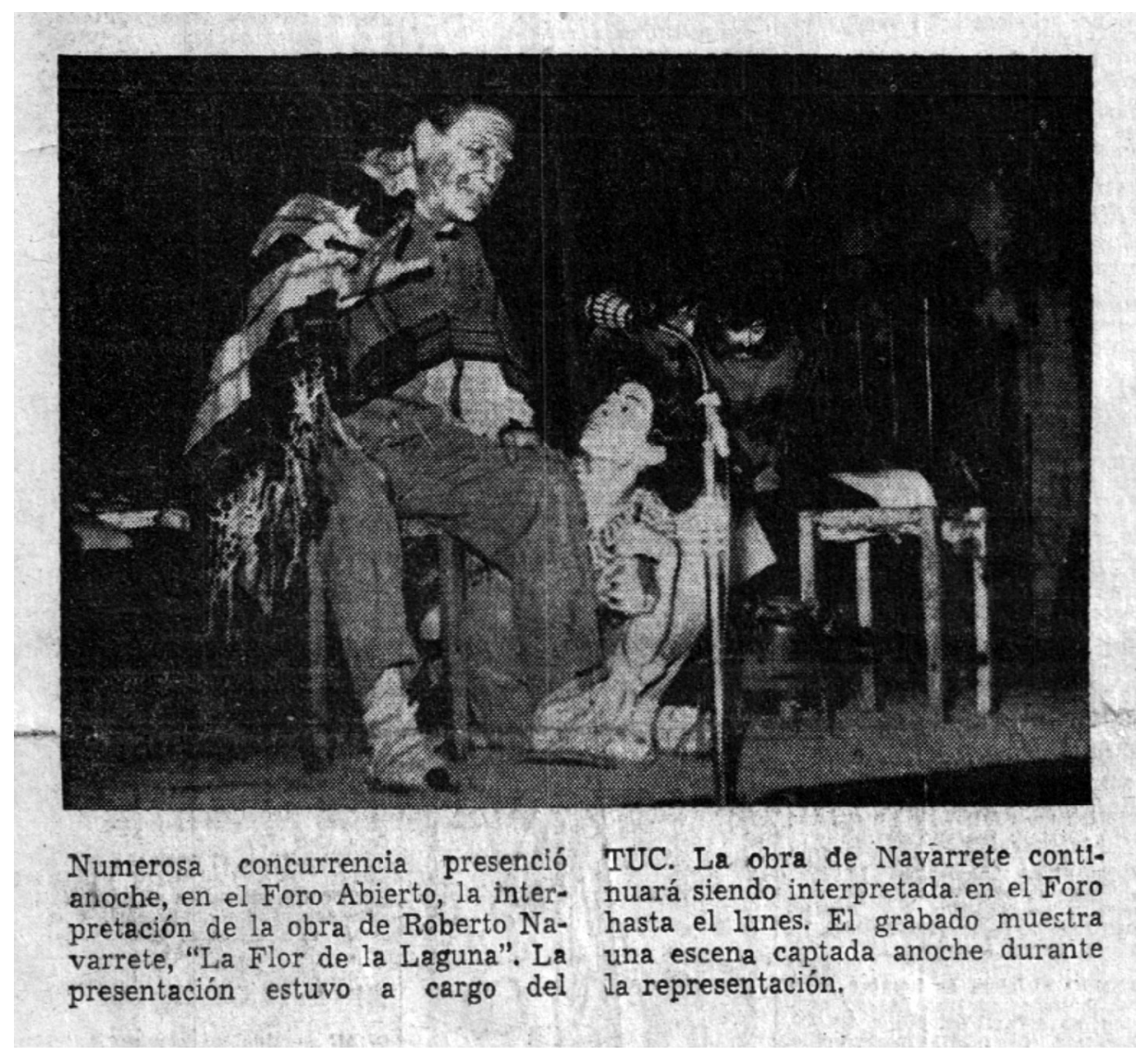

Figura 4: El Sur, 24 de diciembre de 1965, p. 1

\section{LA MÚSICA Y LO MUSICAL EN LA FLOR DE LA LAGUNA}

De acuerdo con el libreto, figuran en la obra cinco canciones originales, atribuidas a Roberto Navarrete en su texto y melodía, con arreglos corales de Eduardo Gajardo. Algunas de ellas se ejecutan en más de una ocasión a lo largo de la obra. Cuatro de ellas se encontraban entre los materiales donados por la familia del dramaturgo. Siguiendo el orden de aparición y respetando el título de las partituras, se denominan respectivamente La flor de la laguna - 4 canciones para Navidad, Canción $N^{o} 4$ de 'La flor de la laguna'- 'toy cortando mimbres, Caballito - 'de la flor de la laguna'y La flor de la laguna - Canción $N^{o} 2$. Además, el libreto señala la entrada del coro con una canción titulada José se llamaba el padre que bien podría tratarse de una canción folclórica así titulada, aunque no disponemos de una transcripción que nos permita acreditarlo con certeza, o si esta se habría interpretado al unísono o en una versión arreglada para voces.

Tres de las canciones antes mencionadas fueron posteriormente publicadas en un libro de partituras con arreglos de Eduardo Gajardo "hechos para el Coro de la Universidad de 
Concepción ${ }^{23}$ ", donde figuran bajo títulos que pueden diferir levemente de las partituras que acompañan el libreto, y que corresponden a las denominaciones con que circularon como parte del repertorio de dicho conjunto vocal, dirigido por Gajardo entre 1964 y 1976. En efecto, la prensa de época señaló que "algunas de ellas han sido ya incluidas en el repertorio del Coro Universitario 24 ", atestiguando que algunos de los arreglos llegaron a tener circulación pública previa al estreno de la obra y reafirmando la idea de que este debió aplazarse un año debido a los conflictos internos del TUC.

Además de las creaciones originales, el libreto señala una simulación de cueca en la escena I, la interpretación de villancicos tradicionales en la escena VII, de los que solo se puntualiza que son ejecutados por un grupo de campesinos con guitarras que pasa por la calle ${ }^{25}$. Incluye además varios momentos que pueden ser entendidos como musicales. Por ejemplo, las intervenciones de un grupo de niñas en cuyas interacciones se evidencia un sentido rítmico de carácter lúdico, idea que es refrendada por la prensa local cuando señala que "juegan un papel importante las rondas con coreografía de la profesora Silvia Ávila $26 "$, como si de una ronda se tratara.

Por otro lado, más allá de la música, la articulación del espacio sonoro figura como un aspecto relevante en la ambientación de la obra. Si bien parece ser una preocupación habitual del autor, la cantidad de menciones al respecto excede a la de sus otras piezas de la época que hemos podido revisar. Acá se señalan gestos como el trinar de los pájaros, el canto del gallo, las risas o el silbido de una tonada campesina.

Las canciones de las que disponemos presentan ciertas características comunes que dan un cierto sentido de unidad a la propuesta musical y permiten sostener la idea de una relación estructural con el desarrollo dramático, donde cumple funciones de orden predominantemente psicológico, de escasa incidencia narrativa, y técnico, dando fluidez y continuidad a las escenas y las transiciones. Por ejemplo, 'toi cortando mimbre funciona, a la manera de un aria, para dar profundidad psicológica al abuelo sustrayéndolo de la temporalidad de la obra para desarrollar la acción de su mundo interno. Por su parte, Caballito ambienta y da sentido a la idea de viaje durante el sueño de José. Traducido a un plano funcional de la relación música-drama, se observa un uso predominante de la música como factor prosopopéyico descriptivo, emocional y de subrayado ${ }^{27}$.

En otro plano, la unidad estética de la música contribuye a la identidad estética y unidad estructural de la obra. Todas las piezas que conocemos se encuentran en metro ternario, con predominancia del 6/8 y uso recurrente de la hemiola, como es característico en los repertorios tradicionales del centro de Chile que fueron tomados como referentes para construir el imaginario musical de la ruralidad. Estructuralmente, siempre encontramos un pasaje que cumple la función de estribillo, aunque cada arreglo difiere en cuanto a las características de ese pasaje y la distribución interna de las secciones. Predominan las

23 Libro impreso sin tapa ni referencias. Contiene ocho arreglos de Eduardo Gajardo, todos referidos a canciones de la tradición folclórica o inspiradas en ella. El documento fue facilitado, de su archivo personal, por Soledad Donoso, profesora del Departamento de Música de la Universidad de Concepción.

24 "Espectáculo de Navidad...", La Patria, 22 de diciembre de 1965, p. 9.

25 Para una presentación esquematizada de este repertorio, ver Anexo 2.

26 "Espectáculo de Navidad...”, La Patria, 22 de diciembre de 1965, p. 9.

27 A falta de categorías funcionales para la música en teatro, se han tomado como referencia Chion (1993), quien distingue entre funciones expresivas, estéticas, estructurales y narrativas, y especialmente Román (2008), quien las categoriza en físicas, psicológicas y técnicas. Con base en esta analogía, los conceptos mencionados se refieren respectivamente a la intención de representar los estados de ánimo de los personajes, construir una atmósfera psicológica ad hoc y remarcar aquellas emociones que el público debiera sentir en los diferentes momentos de la obra. 
tonalidades menores que refuerzan los momentos de nostalgia de la obra. Los arreglos están diseñados privilegiando la alternancia de la melodía entre las diferentes voces, con uso preferente del bajo como voz principal. Mientras tanto, el resto del coro tiende a utilizarse como recurso atmosférico, usando con frecuencia efectos figurativos y sumándose a la declamación del texto solo en aquellos momentos donde se necesita resaltarlo. En ese sentido, hay una diversidad textural que transita por la melodía acompañada, la homofonía con pasajes homorrítmicos y el contrapunto imitativo (ver Figura 5).

Aparecen algunos rasgos excepcionales en La flor de la laguna-Canción $N^{o} 2$ y en Caballito. La primera nos remite a un metro de $3 / 8$ y prescinde de las voces masculinas, sin distanciarse, en todo caso, del modelo de canción-tonada. Caballito, por su parte, presenta algunos tópicos musicales que nos remiten a la figura de la cabalgata, incluyendo el recurso percusivo del galope que acompañaba la ejecución de la pieza ${ }^{28}$. Se asemeja a la célebre canción Mi Caballo Blanco, compuesta nada menos que por Francisco Flores del Campo y popularizada por Los Huasos Quincheros. Aunque el arreglo de Gajardo se ejecuta en un pulso mucho más rápido, aún es posible apreciar semejanzas en el diseño rítmico, melódico, armónico y estructural.

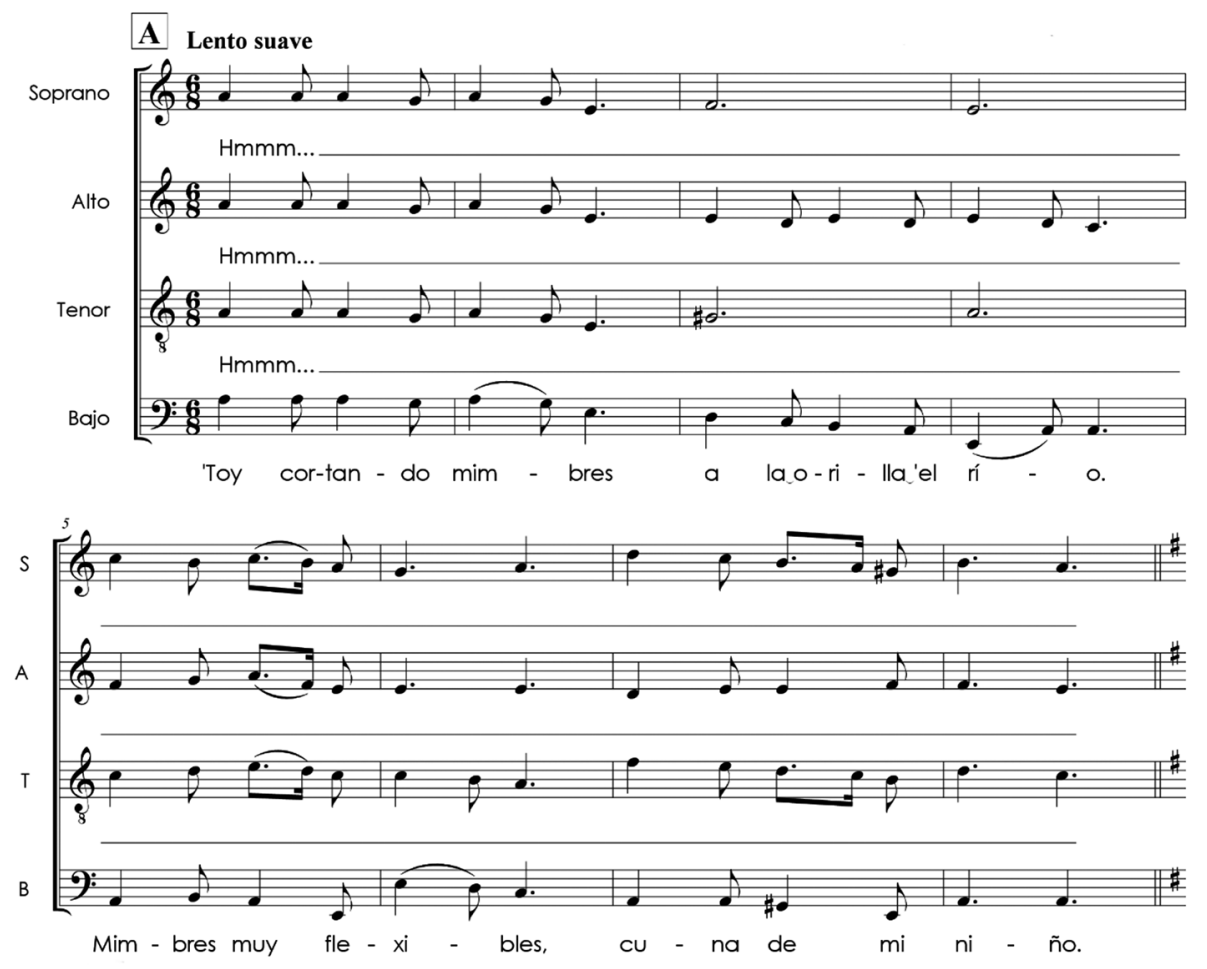

Figura 5: Canción $\mathrm{N}^{\circ} 4$ de La flor de la laguna - 'toy cortando mimbres, cc. 1-8.

28 En el libreto se menciona "galope con timbales", mientras que, según la referencia entregada por Mateo Palma en una entrevista de 2017, que coincide con la grabación de la pieza atesorada en el registro de la radio Universidad de Concepción, interpretada por el Coro de la Universidad de Concepción, este efecto lo realiza un coralista golpeando sobre su carpeta de partituras. 
Algunas de las características señaladas tienen explicaciones bastante plausibles. Eduardo Gajardo siempre demostró afinidad hacia la tradición folclórica. En efecto, un episodio destacado de su carrera temprana fue su participación como director del Conjunto Criollo de la Corporación Sinfónica de Concepción, institución donde además fue ayudante del célebre director coral Arturo Medina McKey. Consecuentemente, la mayoría de sus arreglos corales, muchos de ellos todavía interpretados con frecuencia, remiten a repertorio de raíz folclórica chilena y latinoamericana. Por otro lado, el uso preferente del bajo se debería a que es el registro de su propia voz, pues, como veremos a continuación, él también interpretó al menos una de las canciones de la obra como parte de su repertorio personal. Por último, la cualidad textural de sus piezas y algunos de los efectos sonoros que utiliza derivan de la práctica de la guitarra, instrumento del que fuera un intérprete virtuoso.

Respecto de la ejecución de las piezas, la descripción de la prensa es ambigua al señalar que "otra participación especial tendrá el Coro Universitario, conjunto que grabó las canciones que se interpretan en la obra según una transcripción coral del director Eduardo Gajardo 29 ". Los testimonios orales tampoco dan indicios claros acerca de la naturaleza de esa participación; si las grabaciones mencionadas fueron efectivamente utilizadas para la obra o tuvieron otro tipo de circulación previa o posterior. Pero es posible pensar que el coro no participó directamente en las presentaciones, o al menos no en la totalidad de ellas. Primero, porque se trata de un coro vocacional voluntario, condición que dificulta la regularidad de su presencia durante cuatro días continuos de presentaciones. Segundo, porque tenía su propio programa de Navidad, que debió haberle dificultado compatibilizar con la agenda del TUC. En todo caso, la forma en que la presencia del coro se plantea desde el libreto sugiere que, al menos en intención, este debía formar parte de la puesta en escena. Frente a este antecedente, tampoco es descartable que algunos de los actores pudieran haberse integrado a la ejecución en vivo de las obras desde el escenario.

Pese a lo anterior, podemos defender el estatus de La flor de la laguna como primera tentativa de aproximación a un teatro musical por cuanto esta no se encuentra sujeta al formato en que se hacen presentes los músicos durante el desarrollo de la obra, sino en la medida que la música funciona "no como complemento sino como texto contenedor que recodifica otros textos redistribuyendo productivamente sus sentidos (Corrado 1992: 40)". Tanto más si consideramos que,

las relaciones de fuerza dentro del teatro son mucho más complejas que la constatación de determinadas presencias o ausencias físicas. Una música grabada y lanzada por parlantes puede tener una fuerza inusitada en relación a los elementos con los que interactúa y poco tendrá que ver su fuente (Farías 2011: 21).

Como ya estableciéramos antes, las canciones originales no se limitan a un mero complemento estético, sino que se integran a la dramaturgia. Ya sea estructuralmente, cuando sirven como factor de enlace entre las acciones, o psicológica y emocionalmente, en aquellas piezas que funcionan a la manera de aria, profundizando en el perfil psicológico de algunos roles principales. Esta última, una estrategia que, desde la ópera, arraigó en el cine y el teatro musical. Por último, en aquellos casos donde, como en las intervenciones de las niñas, sin existir música propiamente tal se imprime un carácter de musicalidad en los diálogos que dinamiza la acción dramática. Consideramos que todos estos elementos,

29 “Espectáculo de Navidad...", La Patria, 22 de diciembre de 1965, p. 9. 
y especialmente los que hacen parte del desarrollo psicoemocional de la obra, son factores que, en efecto, producen una redistribución de sentidos.

Por su parte, el estilo de las obras arregladas por Gajardo es un ejemplo notable de discrepancia con las convenciones referidas a la relación entre música y política en Chile. Su caso cuestiona la penetración, operatividad y temporalidad de las representaciones que se han atribuido a estos repertorios luego de su apropiación por parte del Partido Comunista y el proyecto de la Unidad Popular bajo los formatos divulgados por la emergente Nueva Canción Chilena. En primer lugar, la marcada intención política de la obra no se refleja en los textos de Navarrete para sus canciones. Tampoco en sus melodías, más próximas a la versión estereotipada del folclor que, acompañando los procesos de migración campociudad, se había adaptado a formas modernas de circulación mediatizada. La tonada urbana, uno de los principales referentes musicales que se intuyen en la música de Navarrete y Gajardo, es una forma de canción popular que contaba

con la plena complicidad de la élite social, que veía finalmente consolidado un género que representaba sus más antiguas tradiciones y que sabía sobreponerse a los embates de la modernidad, y a las necesidades de identidad de la clase media y de la nueva cultura popular urbana que se instalaba en el país (González y Rolle 2005: 394).

El elepé Canto dormido de Eduardo Gajardo (GEMA, 1969) suma algunas claves para situar la estética musical de La flor de la laguna. Contiene diez piezas arregladas para canto y guitarra, con marcada influencia folclórica. Se incluyen dos tonadas, una cueca, una sajuriana y seis canciones, incluido un nuevo arreglo de 'toy cortando mimbres de Roberto Navarrete. En la reseña que figura al reverso, se lee lo siguiente:

Como observará el auditor, su ejecución guitarrística -de la que, afortunadamente, está ausente el exceso de rasgueo- es de alta calidad técnica. ¿En qué género encasillar sus canciones?

'Neofolklore' es una palabra que dice mucho y no dice nada, Se trata, en realidad, de un conjunto de composiciones en las que lo folklórico alcanza una dignidad poética y musical poco conocida en Chile; en las que lo que se dice tiene un peso intrínseco; en las que, tras su aparente sencillez, se advierte la impresionante cultura musical del intérprete. Pero no nos equivoquemos: ejecutar escalas difíciles, síncopas, arpegios y acordes disonantes, mientras se canta o recita no es sólo un trabajo mecánico, sino medios de expresión a través de los cuales un artista puede traducir más eficazmente su mundo de vivencias, sueños y esperanzas ${ }^{30}$.

Aun cuando se procure escamotear el concepto de Neofolklore, las señas que entrega el comentario coinciden con el discurso que caracterizó a esta corriente estética, que intentó aproximar los referentes folclóricos a las élites sociales mediante la inclusión de recursos propios de la tradición académica, tanto en los arreglos instrumentales y vocales como en la utilización de un estilo de ejecución virtuoso en la guitarra. En el primer párrafo citado de la reseña sintoniza con la idea de que "la práctica de la guitarra académica se institucionaliza en el modo pulsado (Valdebenito 2012: 74)".

30 Benadava, Salvador, "Eduardo Gajardo", Canto dormido (elepé), mayo de 1969, reverso. 
A lo anterior podemos sumar la evasión de las alusiones a la realidad social para representar en cambio una versión bucólica de lo rural. Si bien esta responsabilidad en el texto recae sobre Navarrete, esta distancia entre la música y la intención política subyacente a la obra da cuenta del rezago que existía en Concepción respecto de las formas de representación músico-políticas que ya llevaban algún tiempo fraguándose en Santiago.

Coincidimos con la afirmación de Manuel Vilches cuando advierte que "aunque sus propios exponentes se han encargado de mostrar a la Nueva Canción Chilena como un movimiento rupturista con las otras propuestas musicales ligadas a la raíz folklórica, hay al menos dos de ellas que son sus antecedentes claros (Vilches 2014: 184)", para luego identificar a la proyección folclórica y el Neofolklore como dichos antecedentes y establecer en Cuncumén y Rolando Alarcón a agentes que constatan esa vinculación.

Si esta situación se evidencia en los circuitos principales de la música nacional, ¿qué queda para la música de la provincia, de Concepción en particular, que se desarrolló desde una experiencia y con un ritmo diferente del paso que marcaba la hegemonía cultural capitalina?

En ese sentido, es pertinente preguntarse si la colaboración entre Navarrete y Gajardo que se materializó en la obra La flor de la laguna se inscribe en una narrativa alternativa del itinerario común entre música y política en Chile, que no dialoga mecánicamente con la lógica estereotipada por los discursos oficiales o formatos convencionales de artes escénicas, sino que hace su contribución al desarrollo del teatro nacional emplazada en una lógica evolutiva de sello local. Desde esa consideración, sugerimos que la obra debe entenderse multidimensionalmente en sus diferentes planos de sentido.

Para empezar, prima la intención de elaborar una obra de teatro familiar que, debido a su espectro de público objetivo, echa mano de algunos recursos característicos de la dramaturgia infantil, otorgándose licencia para aproximarse al formato del teatro musical sin riesgo de tacharla como frívola, pues la música adquiere acá una connotación lúdicoeducativa. Se superpone a ello una intención política manifiesta en los tópicos contingentes de la Reforma Agraria y la Reforma Educacional desde una disposición positiva. Por otro lado, la sensibilidad del dramaturgo hacia los temas campesinos, en virtud de su origen, perfila los escenarios y sujetos sociales predominantes en la trama, dando cuenta de una motivación que, si bien también es política, aparece inspirada por un sentido de identidad anclado en lo rural y condiciona su intención poiésica hacia formas de representación de lo político que dialoguen con sus propias inquietudes.

En ese marco, la música parece situarse en el intervalo entre la intención poiésica y el gesto político. Reafirma la identidad estética de la obra desde una noción de lo campesino que si bien puede ser criticada por su apego a las formas estereotipadas de folclor, se integra a la dramaturgia como alternativa para dar visibilidad a aquellas señas de identidad local que, desde sujetos, experiencias, relatos y escenarios locales, son capaces de recrear un mundo de sentido ante la comunidad del Biobío y, por tanto, susceptibles de transmitir este vínculo sensible con el territorio que también se encuentra contenido en el mensaje de la obra. Y si bien este diálogo músico-teatral puede tomarse por rudimentario, es solo la consecuencia de un aprendizaje pendiente que, para el caso, no pesa tanto como la intención de acceder tanto a ese medio como a ese aprendizaje.

Roberto Navarrete -asistido por Eduardo Gajardo- intentó conciliar sus inquietudes personales con las altas expectativas del TUC, tan atento por aquel entonces a horizontes más lejanos que los de su provincia. Al mismo tiempo, quiso hacer una ofrenda a aquella comunidad que le daba sentido a su existencia. Apostó por lo novedoso y lo desconocido, aún a riesgo de ser olvidado por la historia. Y en la confluencia de disímiles referentes dio forma a La flor de la laguna, que hoy recuperamos como testimonio significativo respecto de las particularidades de la escena artística local. 


\section{BIBLIOGRAFÍA}

CÁNEPa, Mario

1995 Historia de los teatros universitarios. Santiago, Chile: Ediciones Mauro.

CHion, MicheL

1993 La audiovisión. Barcelona: Paidós.

Contreras, Marta, Patricia Henríquez y Adolfo Albornoz

2002 Historias del Teatro de la Universidad de Concepción. TUC. Concepción: Universidad de Concepción.

Corrado, Omar

1992 "Posibilidades intertextuales del dispositivo musical". Kreichman, Raquel, Omar Corrado y Jorge Malachevsky, Migraciones de sentidos: tres enfoques sobre lo intertextual. Santa Fe: Universidad Nacional del Litoral, Centro de Publicaciones, pp. 33-51.

FARÍAs, MARTín

2011 "La madre del cordero: Aproximación a una perspectiva intertextual de la música en el teatro". Tesis para optar al grado de Magíster en Artes mención Musicología. Santiago: Universidad de Chile.

2014 Reconstruyendo el sonido de la escena. Músicos de teatro en Chile 1947-1987. Santiago, Chile: Cuarto Propio.

FERnÁndez, Teodosio

1976 "Apuntes para una historia del teatro chileno: Los teatros universitarios (1941-1973)". Anales de Literatura Hispanoamericana, 5, pp. 331-347.

González, Juan Pablo y Rolle, Claudio

2005 Historia Social de la Música Popular en Chile, 1890-1950. Santiago: Ediciones Universidad Católica de Chile.

Henríquez, Patricia; Daniel Pereira, Juan Pablo Amaya y Nicolás Masquiarán

2018 "Teatro chileno de temática campesina. El cochayuyero y La mariposa en el barbecho de Roberto Navarrete Troncoso". Revista Estudios Hemisféricos y Polares, 9 (2), pp. 43-62.

LOUVEL, RENÉ

1988 Crónicas y semblanzas de Concepción. Concepción, Chile: Ilustre Municipalidad de Concepción.

Montealegre, Alberto

1994 "Campus y edificios de la Universidad de Concepción”. Emilio Duhart Arquitecto. Santiago: Ediciones ARQ pp. 100-105. Disponible en www.memoriachilena.cl/archivos2/pdfs/ MC0030616.pdf [acceso: 16 de octubre de 2017]

NAVARRETE, ROBERTO

1963 El cochayuyero. Estampa campesina en un acto, dividido en dos cuadros. (Libreto original mecanografiado.) [Archivo personal de Roberto Navarrete.]

1965 La flor de la laguna. (Libreto original mecanografiado y partituras) [Archivo personal de Roberto Navarrete.]

1969a La mariposa en el barbecho. (Libreto original mecanografiado.) [Archivo personal de Roberto Navarrete.]

1969b Navidad en la aldea. Estampa navideña en dos cuadros. (Libreto original mecanografiado.) [Archivo personal de Roberto Navarrete.]

Piña, JuAn ANDrÉs

2014 Historia del Teatro en Chile (1941-1990). Santiago, Chile: Taurus.

Román, Alejandro

2008 El lenguaje musivisual. Semiótica y estética de la música cinematográfica. Madrid, España: Mousiké. 
Valdebenito, Mauricio

2012 "Práctica guitarrística chilena, urbana y popular en las décadas de 1950 y 1960: Humberto Campos, Juan Angelito Silva y Fernando Rossi”. Tesis para optar al grado de Magíster en Artes, mención Musicología. Santiago, Chile: Facultad de Artes, Universidad de Chile.

Vilches, MANUEL

2014 "La gloria desde la vidriera: Rolando Alarcón y la consagración de la Nueva Canción Chilena", Palimpsestos Sonoros. Reflexiones sobre la Nueva Canción Chilena. Editado por Eileen Karmy y Martín Farías. Santiago, Chile: Ceibo, pp. 183-199.

\section{Fonografía}

Gajardo, Eduardo

1969 Canto dormido (elepé). Concepción, Chile: GEMA.

\section{Otras fuentes}

Archivo personal, Soledad Donoso.

Diario El Sur de Concepción.

Diario La Patria de Concepción.

Entrevista concedida por Mateo Palma a Nicolás Masquiarán, Concepción, 24 de abril de 2017.

\section{ANEXO 1: \\ FICHA TÉCNICA DE LA FLOR DE LA LAGUNA}

$\begin{array}{ll}\text { Dirección: } & \text { Roberto Navarrete Troncoso } \\ \text { Libreto: } & \text { Roberto Navarrete Troncoso } \\ \text { Decorados: } & \text { Albino Echeverría } \\ \text { Vestuario: } & \text { Nina García } \\ \text { Música: } & \text { Roberto Navarrete Troncoso (melodía y letra); Eduardo Gajardo (arreglos) } \\ \text { Ejecución: } & \text { Coro de la Universidad de Concepción; Eduardo Gajardo (director) } \\ \text { Coreografía: } & \text { Silvia Ávila }\end{array}$

Reparto

$\begin{array}{ll}\text { José: } & \text { María Inés Chavarría } \\ \text { Padre: } & \text { Fernando Farías } \\ \text { Madre: } & \text { Gloria Varela } \\ \text { Abuelo: } & \text { Vicente Santamaría } \\ \text { Sobrina: } & \text { Mireya Mora } \\ \text { Maestra: } & \text { Brisolia Herrera } \\ \text { Alumna 1: } & \text { Nancy Fierro } \\ \text { Alumna 2: } & \text { Inés González } \\ \text { Niño 1: } & \text { Fernando Farías } \\ \text { Niño 2: } & \text { Mireya Mora } \\ \text { Peones: } & \text { Alberto Villegas } \\ & \text { Jorge Gajardo } \\ & \text { Gonzalo Palta } \\ & \text { Víctor García } \\ & \text { Roberto Parada } \\ & \text { Guillermo Lobo }\end{array}$


Ernesto Hurel

Daniel Mardones

Fredy Winter

Niñas: Alumnas del Liceo Experimental.

Extras: Grupo de Teatro de la Escuela Dental.

ANEXO 2:

CANCIONES

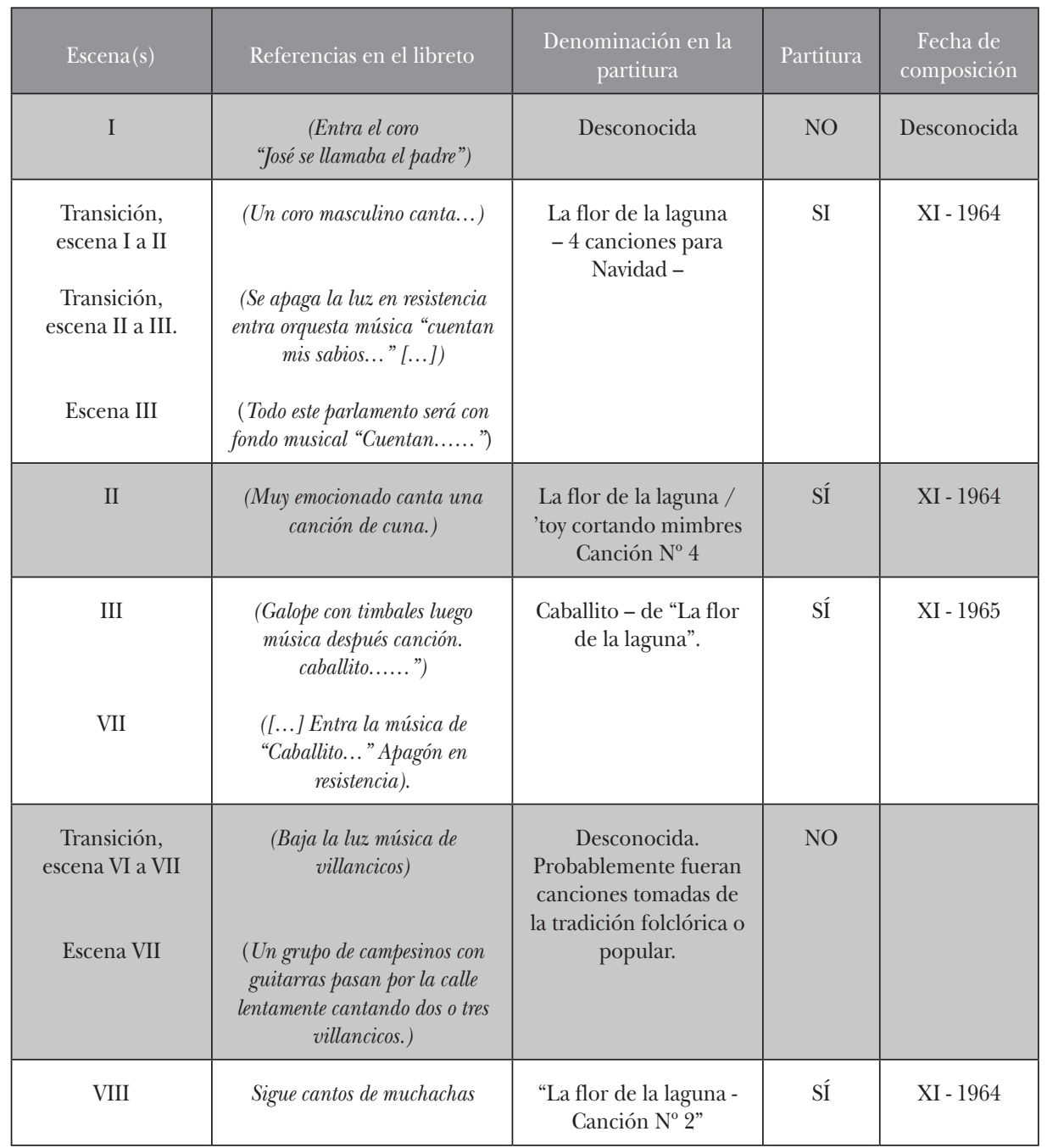

